\title{
Forest resources: its extent and decay in Osmanabad District of Maharashtra State
}

\author{
Rede H.N.* \\ * Department of Geography, S.C.S.College, Omerga, Tal.Omerga, 413606, Dist. Osmanabad, Maharashtra, \\ India, Mobile-919420770024
}

\begin{abstract}
Present paper describes the prominent features of forest cover and its extent and decay in the Osmanabad district. The district having geographical area of 7512.40 sq.km., consists eight tahasils and is inhabited by 14,86,586 population (as per 2001 census). The area under forest during 1991-92 was 5062.76 sq.kms. $(0.48 \%$ of the total geographical area), it increased to $7982.79 \mathrm{kms}$. $(0.81 \%)$ till $2001-02$. The percentage of forest area in the district is registered very less than the norms set by the (22\%) National Forest Policy. The district has favourable physiographic conditions for the proper growth of natural vegetation (2.64\% of land area not available for cultivation). But the main obstacles in the forest development are adverse climatic condition i.e. scanty and tiny rainfall, wherever, the drought are frequent. Although $0.33 \%$ positive changes in forest area are recorded in the district (2001-02). Because various forest and soil conservation programmes are intensified by government in the Osmanabad district. The hill tracts are covered by dry deciduous forest. However, the population, which inhabited this region is increasing over the decades. The economic activity of these people is mainly concentrated around agricultural practices and livestock rearing.
\end{abstract}

Key words- forest cover, depletion of forest, forest development strategy

\section{Introduction}

A Forest is a natural ecosystem having multispecies and multiaged trees, as dominant community. Forest cover about one third (1/3) of the earth land surface, of which about one half $(1 / 2)$ is occupied by tropical forest. Of all the human activities which lead to the tropical deforestation is most hazardous. Forest are recognized as the world's largest carbon sinks, because of their large biomass (Jager, 1983). Population growth of an ever increasing rate is a major factor and is fast losing the capacity of earth to support life. The experience of deforestation, loss of bio-diversity, soil erosion, atmospheric pollution and drought are living examples of the world's at stake. Human action by itself has endangered the environment. Man for his very livelihood depends upon plants. Forest is the integral prior part of human life. Plants have given precious place in our culture. But with ever growing technical knowledge, no corner of the earth has been left untouched.

\section{Data base and methodology}

The present study relies upon secondary data. The secondary data concerning forest area was collected from Sub-division Forest Office, Osmanabad. The gathered data were then processed and mapped. Choropleth technique of mapping was used to portray the spatial variations clearly.

\section{Study region}

Osmanabad district is one of the chronically drought-prone areas in the country. It is situated between $17035^{\prime} \mathrm{N}$ to 18040 ' $\mathrm{N}$ latitudes and 75016'E to 76040'E longitudes (Map No.1.1). large area of the district is covered by Balaghat Ranges and uneven with patches of low level plain. Climate of the district is dry, as daily mean maximum temperature range between $300 \mathrm{C}$ to $390 \mathrm{C}$ and minimum temperature range between $180 \mathrm{C}$ to $210 \mathrm{C}$, with the highest temperature of $450 \mathrm{C}$ recorded in the month of May. The average annual rainfall is registered $710 \mathrm{~m} . \mathrm{m}$. (2001). The soil of the district is essentially derived from the Deccan Trap. The soil of the district can broadly classified into four groups- shallow soil, medium soil, medium deep, and deep soil.

\section{Forest covers and changes therein}

Forest from distinct ecosystem, in fact Osmanabad district, has very poor in forest cover with only $0.81 \%(2001)$ of the total geographical area of the district. The nature and character of forest in the district does not indicate any dense growth of tree population with different variety of plants. Forest are scattered in the form of the small patches with variety of plants. The forest of the district may be described as dry mixed deciduous and thorny open scrub types. Table No.1 depicts that, the distribution of forest cover in the tahasil level is very low in proportion. During the decade under consideration (19912001) total area under forest has not shown any substantial change (Map No.2.B), but it showed a small increase of $0.33 \%$ (3392.59 hectares) in 2001. Tahasilwise distribution of forest indicates very acute and most uneven (Map No.2.A). The concentration of forest is high in Tuljapur (1.76\%), Osmanabad (1.58\%) and Bhum (1.6\%) tahasils in the year 2001 census. These tahasils are located on Balaghat Range, where coefficient of rainfall variability marked $26.98 \%$, $30.92 \%$ and $33.85 \%$ respectively.

While Omerga and Paranda tahasils are registered negative change in area under forest from 1991 to 2001. 
In brief, it may be mentioned that the agro-based economy, $84.31 \%$ population are living in rural area, ever increasing demand for forest wood from rural people, large proportion of district area comes in Krishna Valley Development of Corporation, so the work to construct irrigation projects is in progress. Ultimately the cultivated area under irrigation is increased, which also affected on forest cover.

\section{Depletion of forests}

The depletion of the forest cover is mainly due to ever increasing population pressure on land for agriculture, indiscriminate grazing, which has denudation of forest. Moreover, the cultivators have phenomenally grown from $2,14,496$ in 1981 to about 2,15,302 in 2001, which indicating the increased pressure on agriculture land. As a consequence, the total cropped area of the district has increased from $6,69,112$ hectares in 1991 to $7,20,600$ hectares in 2001. All these facts and figures lead to the inference that the intensive cultivation is mainly responsible for the destruction of forest cover in the district, than all other agents of deforestation put together. In addition another reason for depletion of forest in the district is introduction of modern agricultural technique i.e. irrigation development and mechanization of agriculture. Thirteen's of millions of rural peoples depend on forest for fuel, fodder and raw materials for village industry and shelter. Per capita forest area marked only 0.05 hectare in the year 2001. For them, forest had only a present and a past, no future; thus, they restored to ruthless and accelerate exploitation of available forest, which still continues with more serious black lashes, earth has ever witnessed. India alone is losing more than 1.5 million hectares of forest cover each year and 22 million hectares of forest have been destroyed during the three decades due to over exploitation and misuse and conversion to agricultural fields. The depleted forest wealth would simply deprive the man of economic and environmental values offered by forest.

\section{Strategy for forest development}

Being a drought-prone district, maintenance of ecological balance is one of the most important problem today. Though, it is necessary to take up massive effort on war footing to develop forest cover in the district, for this following strategy can be apply.

a. There are medium, minor percolation tanks in the district, where silting process gradually take place and do not filling with meager rainfall. The foreshore of these tanks can be planted with subabul, neem plantations.

b. Plantation of drought resistant species in large parts of the hill tracts, which are devoid of any vegetative cover.

c. Depending upon the suitability of site and topography and along road side the species like niligiri, neem, etc can be planted extensively.

d. Pasture development can be taken up on the barren land, hills, sloppy soils. Having all the afforestation schemes, it is extreme essential to convert this dry area gradually into a green belt for balancing the ecosystem.

\section{Conclusion}

The data regarding forest cover in the district, carried out the information, reveals the significant change with respect to forest cover, degradation and retrogressing of forest and subsequent changes and the extension of agricultural practices. All these unplanned and unscientific activities are creating and adverse effect on forest area of Osmanabad district. Strategy must be evolved to minimize such adverse effect and improvement in the forest area.

\section{Reference}

[1] Deshpande C.D. Geography of Maharashtra, N.B.T. of India, New Delhi

[2] Dikshit K.R. Forest Ecology

[3] Rail R.K. Deforestation and its Impact on Environment. McGraw Hill, Geographer Vol.XX (2004) pp.112

[4] Reddy Kamlakar (Ed.) Land use Planning and Environmental Management, Printed by Director, Dept. of Publication \& Press Osmania University Hyderabad.

[5] Shafi Mohammad \& Mehendi Raza (Ed.) Geography of Environment, Rawat Publications Jaipur.

[6] Census hand-book of Osmanabad District, $1981,1991 \& 2001$. 

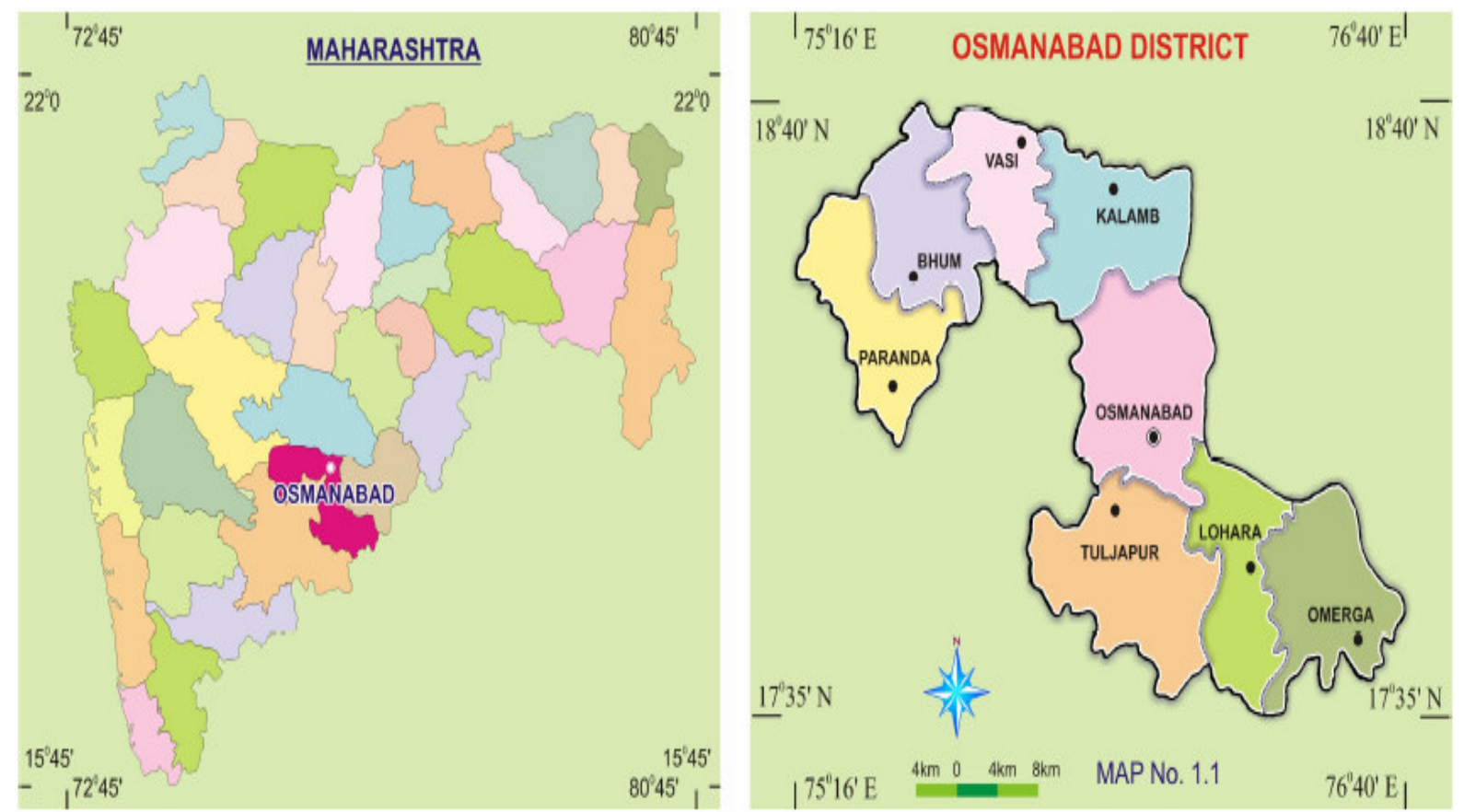

Fig 1- Location map

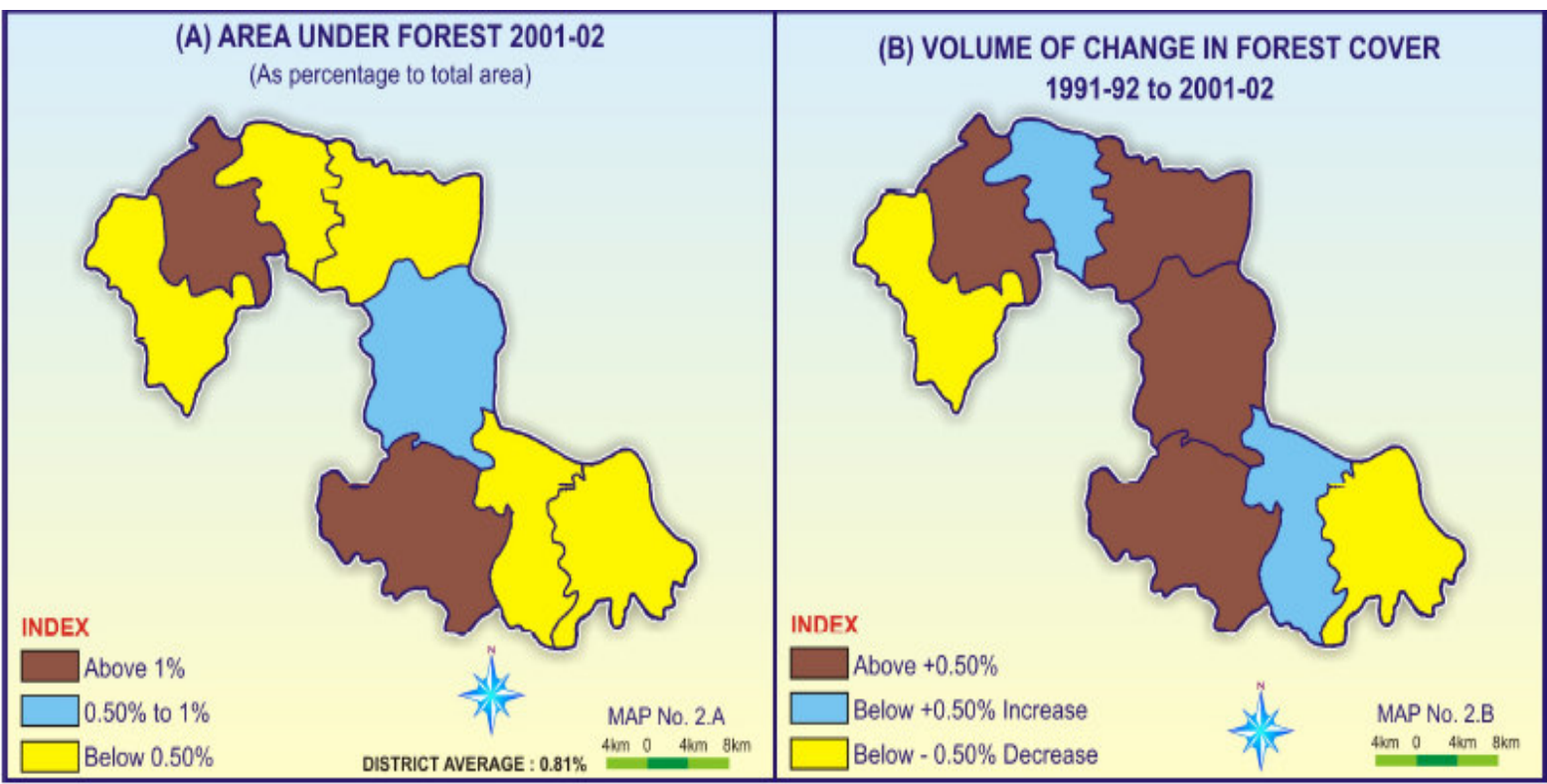

Fig 2- Location map 
Table No. 1 : Tahasil-wise Change in Forest area from-1991 to 2001.

\begin{tabular}{|c|c|c|c|c|c|c|}
\hline \multirow[t]{2}{*}{$\begin{array}{l}\text { Sr. } \\
\text { No. }\end{array}$} & \multirow[t]{2}{*}{$\begin{array}{l}\text { Name of } \\
\text { the Tahasil }\end{array}$} & \multicolumn{2}{|c|}{ Forest area (hect.) } & \multicolumn{2}{|c|}{$\begin{array}{c}\% \text { of forest area to } \\
\text { total geographical } \\
\text { area of tahasil }\end{array}$} & \multirow[t]{2}{*}{$\begin{array}{c}\text { Change } \\
\text { in forest } \\
\text { cover }\end{array}$} \\
\hline & & 1991 & 2001 & 1991 & 2001 & \\
\hline 1 & Osmanabad & 896.73 & 2156.57 & 0.65 & 1.58 & +0.93 \\
\hline 2 & Tuljapur & 1742.97 & 2672.96 & 1.08 & 1.76 & +0.68 \\
\hline 3 & Bhum & 287.00 & 634.93 & 1.08 & 1.60 & +0.52 \\
\hline 4 & Paranda & 243.78 & 236.48 & 0.20 & 0.19 & -0.01 \\
\hline 5 & Vasi & 494.52 & 763.03 & 0.21 & 0.24 & +0.03 \\
\hline 6 & Kalamb & 305.96 & 1522.95 & 0.25 & 1.26 & +1.01 \\
\hline 7 & Omerga & 598.91 & 121.00 & 0.19 & 0.07 & -0.12 \\
\hline 8 & Lohara & 145.46 & 224.00 & 0.21 & 0.35 & +0.14 \\
\hline & Total & 4715.33 & 8107.92 & - & - & +3.18 \\
\hline
\end{tabular}

Source: District Sub-division Forest Office, Osmanabad 